\title{
Reductive carboxylation mediated oxidative stress defense supports anchorage independent cell growth
}

\author{
Lei Jiang ${ }^{1 *}$, Matthew Mitsche ${ }^{2}$, Ralph Deberardinis ${ }^{1}$, Karine Smans ${ }^{3}$ \\ From Metabolism, Diet and Disease 2014: Cancer and metabolism \\ Washington DC, USA. 28-30 May 2014
}

\section{Background}

Cancer cells consume large amount of glutamine for growth and proliferation. In normal mitochondria, glutamine is converted to $\alpha$-ketoglutarate, which is further oxidized through the TCA cycle [1]. Recent studies find that under certain extreme conditions, such as mitochondria dysfunction and hypoxia, cells use glutamine through reductive carboxylation ( $\mathrm{RC}$ ) to generate acetyl-CoA for lipogenesis. During tumor development, the acquisition of anchorage independence enables cancer cells to survive without their natural extracellular matrix, but this comes at the price of increased oxidative stress [2]. Here we examined reprogramming of glutamine metabolism during adaptation to growth of anchorage independent tumor spheroids, including reprogramming of pathways that counteract production of reactive oxygen species (ROS).

\section{Materials and methods}

Metabolic differences were compared in cancer cells cultured under monolayer adhesion and suspension spheroid condition. ${ }^{13} \mathrm{C}$ labeled glucose or glutamine cultured cells were extracted for metabolites, followed by gas chromatography mass spectrometry analysis.

\section{Results}

Here we show that spheroid culture is associated with an induction in mitochondrial ROS. Under these conditions, cells prefer to use cytosolic RC rather than the intra-mitochondria oxidative pathway to initiate the glutamine metabolism. Cytosolic isocitrate dehydrogenase 1 (IDH1) is the only isoform of IDHs catalyzing RC in spheroid culture.

${ }^{1}$ Children's Medical Center Research Institute, UT Southwestern Medical Center, Dallas, TX, USA

Full list of author information is available at the end of the article
Blocking the cytosolic RC with an IDH1 specific inhibitor induces mitochondrial ROS, and impairs spheroid growth, which could be rescued by antioxidant N-Acetyl Cysteine (NAC) co-treatment. ${ }^{13} \mathrm{C}$ labeling in isolated mitochondria reviewed the import and oxidation of citrate, using a pathway that may result in the transfer of NADPH from cytosol to mitochondria.

\section{Conclusions}

Our finding indicates that IDH1 dependent reductive carboxylation incorporates cytosolic reducing equivalent into citrate, which gets into the mitochondria and releases the reductive equivalent as $\mathrm{NADPH}$ through the oxidative TCA cycle. These results reveal a novel reductive carboxylation mediated NADPH transportation pathway, to protect cells from detachment induced mitochondria oxidative stress.

\section{Acknowledgements}

Work was supported by a research grant from the NIH CA157996.

\section{Authors' details}

${ }^{1}$ Children's Medical Center Research Institute, UT Southwestern Medical Center, Dallas, TX, USA. ²Eugene McDermott Center for Human Growth and Development, UT Southwestern Medical Center, Dallas, TX, USA. ${ }^{3}$ Oncology, Janssen Research \& Development, Beerse, Belgium.

Published: 28 May 2014

\section{References}

1. DeBerardinis RJ, Mancuso A, Daikhin E, Nissim I, Yudkoff M, Wehrli S, Thompson CB: Beyond aerobic glycolysis: transformed cells can engage in glutamine metabolism that exceeds the requirement for protein and nucleotide synthesis. Proc Natl Acad Sci U S A 2007, 104:19345-19350.

2. Schafer ZT, Grassian AR, Song L, Jiang Z, Gerhart-Hines Z, Irie HY, Gao S, Puigserver $P$, Brugge JS: Antioxidant and oncogene rescue of metabolic defects caused by loss of matrix attachment. Nature 2009, 461:109-113. 
doi:10.1186/2049-3002-2-S1-P30

Cite this article as: Jiang et al.: Reductive carboxylation mediated oxidative stress defense supports anchorage independent cell growth. Cancer \& Metabolism 2014 2(Suppl 1):P30.

Submit your next manuscript to BioMed Central and take full advantage of:

- Convenient online submission

- Thorough peer review

- No space constraints or color figure charges

- Immediate publication on acceptance

- Inclusion in PubMed, CAS, Scopus and Google Scholar

- Research which is freely available for redistribution

Submit your manuscript at www.biomedcentral.com/submit

O) BioMed Central 